\title{
PENERAPAN MODEL PROBLEM BASED LEARNING BERBANTU MEDIA AUDIO VISUAL UNTUK MENINGKATKAN BERPIKIR KRITIS KELAS 4 SD
}

\author{
R. Susilowati ${ }^{1}$, S. C. Relmasira ${ }^{2}$, A. T. A Hardini ${ }^{3}$ \\ ${ }^{1,2,3}$ Pendidikan Guru Sekolah Dasar, Universitas Kristen Satya Wacana, Salatiga \\ e-mail: 292014183@student.uksw.edu'1, Stefanus.relmasira@staff.uksw.edu², \\ tyas.asri@staff.uksw.edu ${ }^{3}$
}

\begin{abstract}
ABSTRAK
Jenis penelitian ini adalah penelitian tindakan kelas. Tujuan penelitian ini meningkatkan kemampuan berpikir kritis siswa dengan penerapan model pembelajaran Problem Based Learning berbantu media Audio Visual. Data dikumpulkan dengan menggunakan lembar observasi dan tes evaluasi. Rata-rata persentase kemampuan berpikir kritis siswa secara keseluruhan pada lembar observasi pada pra siklus 13,8\%, meningkat di siklus I $69 \%$ dan kembali mengalami peningkatan pada siklus II 96,5\%.Dan persentase keseluruhan pada hasil tes evaluasi siklus I 44,8\% meningkat pada siklus II 96,6\%. Dengan demikian hasil penelitian menunjukkan bahwa penerapan model problem based learning berbantu media audio visual mampu meningkatkan kemampuan berpikir kritis siswa.
\end{abstract}

Kata kunci: Problem Based Learning, Audio Visual, Berpikir Kritis

\begin{abstract}
This type of research is a class action research. The purpose of this research enhances students ' critical thinking ability by application of Problem Based Learning with Audio Visual Media. Data were collected by using a sheet of observation and evaluation tests. The average percentage of critical thinking ability of students overall observation sheet on precyae $13.8 \%$ increase in cycle cycle I $69 \%$ and increased again in cycle II $96.5 \%$. And the overall percentage on the test results the evaluation cycle I $44.8 \%$ increase in cycle II $96.6 \%$. Thus the results showed that the application of problem based learning with audio visual media is able to enhance the critical thinking ability of students.
\end{abstract}

Keywords: Problem Based Learning, Audio Visual, Critical Thinking

\section{PENDAHULUAN}

Era globalisasi yang diiringi dengan banyaknya perubahan dan pesatnya perkembangan ilmu pengetahuan dan teknologi, memberikan banyak manfaat dan kemudahan bagi manusia dalam melaksanakan aktivitasnya dalam kehidupan sehari-hari. Dengan demikian, tantangan yang dihadapi generasi yang akan datang pun akan semakin berat. Oleh sebab itu, Pendidikan menjadi suatu hal yang penting. Penting karena pendidikan memiliki peran besar dalam membentuk karakter, mental dan perkembangan pengetahuan siswa, pendidikan juga bisa menjadi investasi masa depannya sendiri agar dapat menjadi generasi yang cerdas, bermartabat dan bisa menjadi generasi-generasi penerus bangsa yang berkualitas serta mampu bersaing dengan dunia luar. Pendidikan di sekolah dasar merupakan awal untuk mengembangkan kemampuan dasar, menulis, berhitung, membaca, menyimak dan ketrampilan dasar lainnya. Siswa sekolah dasar mengalami perkembangan dalam tingkat berpikirnya sehingga memerlukan stimulus dengan cara memperkaya pengalaman belajar yang bermakna melalui pemberian persoalan 
untuk memecahkan masalah atau fenomena yang berhubungan dengan aspek-aspek kehidupan manusia. Tantangan perubahan masa depan yang diiringi perkembangan ilmu pengetahuan menuntut pembelajaran untuk dapat lebih meningkatkan kemampuan berpikir kritis siswa, karena salah satu tujuan pembelajaran adalah melatih kemampuan ketrampilan berpikir kritis siswa. Menurut Redhana (2012:353) ketrampilan berpikir kritis penting untuk diajarkan kepada siswa, agar siswa dapat menolong dirinya dan orang lain dalam menghadapi masalah dalam kehidupan. Faiz (2012:3) menyatakan bahwa berpikir kritis menuntut 4 jenis keterampilan, yaitu: keterampilan menganalisis, keterampilan melakukan sintesis, keterampilan memahami serta memecahkan masalah, dan keterampilan menyimpulkan. Dengan berpikir kritis siswa dapat meningkatkan kemampuan pemahaman dan penguasaan terhadap materi pembelajaran secara mendalam. Sehingga, siswa dapat menemukan cara untuk penyelesaian masalah-masalah yang diberikan oleh guru.

Menurut Suparno \& Iranto (2014:4445) kemampuan berpikir kritis adalah kemampuan berpikiri tingkat tinggi yang tujuannya untuk mengkaji situasi, fenomena, masalah atau pertanyaan untuk mendapatkan sebuah hipotesis atau kesimpulan untuk pengambilan keputusan secara rasional atas apa yang telah diyakini dan dikerjakan dengan melalui analisis, penafsiran, kesimpulan, evaluasi dan penjelasan. Selanjutnya menurut Christina \& Kristin (2016:222) berpikir kritis merupakan kemampuan seseorang dalam menemukan informasi dan pemecahan dari suatu masalah dengan cara bertanya kepada dirinya sendiri untuk menggali informasi tentang masalah yang sedang dihadapi Menurut Ennis (dalam Rusyna, 2014:110) mengungkapkan bahwa ada 12 indikator berpikir kritis yang terangkum dalam 5 kelompok ketrampilan berpikir antara lain: (1) memberikan penjelasan yang sederhana; (2) membangun keterampilan dasar (basic support); (3) menyimpulkan (inference); (4) memberikan penjelasan lanjut (advance clarification); (5) mengatur strategi dan taktik (strategies and tactics). Terdapat 6 indikator kemampuan berpikir kritis yang menjadi focus penelitian yang dilakukan, yaitu: (1) menganalisis argument, (2) mampu bertanya, (3) mampu menjawab pertanyaan, (4) memecahkan masalah, (5) membuat kesimpulan, (6) mengevaluasi dan menganalsis hasil pengamatan.

Kurikulum 2013 mengatur jalannya pelaksanaan pembelajaran yang digunakan pada jenjang SD/MI dan sederajat untuk menggunakan pembelajaran tematik terpadu. Hal ini ditegaskan kembali dalam Permendikbud No. 65 tahun 2013 tentang Standar Proses bahwa pembelajaran tematik terpadu di SD/MI/SDLB/Paket A disesuaikan dengan tingkat perkembangan siswa sekolah dasar. Menurut Puspita \& Yuhelman (2017:33) pentingnya pembelajaran tematik diterapkan di sekolah dasar karena tahap ini siswa masih melihat segala sesuatu sebagai satu keutuhan (holistik), perkembangan fisiknya tidak akan bisa dipisahkan dengan perkembangan mental, sosial, dan emosionalnya. Sehingga, guru dan siswa harus maksimal mempersiapkan pembelajaran, keduanya dituntut untuk mengembangkan ketrampilan High Order Thingking Skill (HOTS) dalam kegiatan pembelajaran dikelas dimana siswa dan guru harus berpikir tingkat tinggi.

Kenyataan di SD Negeri Ledok 07 Salatiga masih belum sesuai dengan harapan. Kemampuan berfikir kritis siswa khususnya pada pembelajaran tematik belum menunjukkan hasil yang memuaskan. Dalam pelaksanaan pembelajaran belum menggunakan model-model pembelajaran inovatif yang dapat melatih dan mengembangkan kemampuan berfikir kritis siswa. Pengembangan kemampuan berpikir kritis siswa masih belum terlihat dalam proses pembelajaran. Itu terlihat pada saat pembelajaran di kelas, hanya beberapa siswa saja yang menjawab pertanyaan dari guru dan saat proses pembelajaran menunjukkan tidak adanya respon yang diberikan siswa terhadap apa yang disampaikan oleh guru. Misalnya saat guru menjelaskan, siswa hanya mengikuti langkah guru tersebut tanpa mempertanyakan alasan pengambilan langkah tersebut dan pertanyaan dari siswa juga belum menunjukkan pertanyaan kritis 
mengenai materi yang sedang dipelajari, pertanyaan yang di ajukan siswa sebatas ingatan dan pemahaman seperti dimana, siapa, berapa, dan kapan. Pada waktu peneliti bertanya menggunakan pertanyaan kritis seperti apa, bagaimana, dan mengapa siswa tampak kesulitan dalam menyampaikan pendapat atau jawabannya, hasil observasi pembelajaran peneliti juga melihat hasil skor siswa dalam mengerjakan soal uraian dan analisis yang membutuhkan tingkatan berpikir kritis masih sangat rendah saat mengerjakan soal uraian, peneliti melihat ketika siswa mengerjakan soal, siswa telihat mengerjakan soal tanpa mengidentifikasi masalah yang diberikan sehingga jawaban yang diberikan siswa tidak sesuai dan terkesan seadanya. Data hasil observasi kemampuan berpikir kritis siswa kelas 4 sebelum tindakan dapat di lihat pada Tabel 1.

Tabel 1. Hasil Pengamatan Kemampuan Berpikir Kritis Sebelum Dilakukan Tindakan

\begin{tabular}{clcl}
\hline No & \multicolumn{1}{c}{ Indikator } & $\begin{array}{c}\text { Pra Siklus } \\
\text { Skor rata-rata }\end{array}$ & \multicolumn{1}{c}{ Kriteria } \\
\hline 1 & Menganalisis Argumen & 48 & Sangat tidak kritis \\
2 & Mampu bertanya & 52 & Tidak kritis \\
3 & Mampu menjawab pertanyaan & 53 & Tidak kritis \\
4 & Memecahkan masalah & 44 & Sangat tidak kritis \\
5 & Membuat Kesimpulan & 50 & Tidak kritis \\
6 & Keterampilan mengevaluasi dan & 51 & Tidak kritis
\end{tabular}

Hal-hal tersebut menunjukkan bahwa siswa tidak secara aktif memahami, menganalisis dan mengevaluasi apa yang disampaikan oleh guru baik dalam penyampaian materi maupun pemecahan masalah atau dengan kata lain kemampuan berpikir kritis siswa masih rendah.

Dari hasil data awal observasi menunjukkan bahwa pembelajaran tematik belum optimal. Hal in disebabkan karena dalam kegiatan pembelajaran yang dilakukan guru masih menggunakan metode ceramah, hanya mengikuti langkah-langkah dibuku guru. Hal tersebut menyebabkan keaktifan siswa dalam mengikuti pembelajaran rendah, fokus siswa dalam belajar cenderung terpecah.. Sehingga pembelajaran menjadi membosankan bagi siswa dan tidak menarik yang mengakibatkan kemampuan berpikir kritis siswa rendah. Alternatif yang dapat digunakan untuk pemecahan masalah tersebut adalah dengan penggunaan model pembelajaran yang melibatkan siswa untuk berpikir kritis dan terlibat langsung secara aktif dalam kegiatan pembelajaran. Maka peneliti memilih salah satu model pembelajaran yang bisa diterapkan sesuai dengan keadaan tersebut di atas dengan model Problem Based Learning (PBL) berbantu media Audio Visual. Menurut Rahmadani \& Anugraheni (2017:241-250) Problem Based Learning merupakan pendekatan pembelajaran yang menggunakan permasalahan dunia nyata sebagai suatu konteks, untuk mengembangkan kemampuan berfikir kritis serta kemampuan pemecahan masalah siswa dalam memahami konsep dan prinsip yang esensi dari materi pelajaran. Selanjutnya, menurut Rahmawati \& Hizqiyah (2017:23) dalam PBL, siswa dihadapkan pada suatu permasalahan, selanjutnya secara berkelompok, siswa akan berdiskusi untuk mencari solusi atas permasalahan tersebut untuk mendapatkan solusinya.

Menurut Zakiyah, dkk (2017:232-233) penerapan model problem based learning dilaksanakan dengan langkah-langkah sebagai berikut: (1) Mengidentifikasi pokok permasalahan; (2) Membuat perencanaan pemecahan masalah; (3) Melaksanakan penyelidikan untuk memecahkan masalah; (4) Melaporkan hasil penyelidikan; (5) Menganalisis proses pemecahan masalah. Dengan demikian menurut Virgiana \& Wasitohadi (2016:103) langkah-langkah 
model problem based learning adalah diawali dengan pemberian masalah atau topik masalah kepada siswa di mana masalah tersebut merupakan permasalahan nyata yang dialami dalam kehidupan seharhari siswa, siswa bekerja sama dalam kelompok untuk menyelesaikan masalah dan menemukan pengetahuan baru. Menurut Fakhriyah (2014:100) beberapa kelebihan penerapan problem based learning meliputi pembahasan materi yang sangat luas, diskusi yang berjalan sangat aktif serta mampu mengembangkan kemampuan berpikir kritis. Menurut Fakhriyah (2014:100) kelemahan problem based learning ialah: langkah pembelajaran yang tidak dapat dilaksanakan dalam waktu singkat. Penerapan problem based learning membutuhkan waktu yang cukup lama, pembelajaran mengharuskan aktivitas belajar mandiri setiap siswa, serta terkadang masih ada beberapa siswa yang mengandalkan teman satu kelompoknya.

Sebagai pendukung model pembelajaran Problem Based Learning peneliti memilih media Audio Visual. Menurut Kustandi, dkk (2013:8) media pembelajaran adalah alat yang mendukung proses pembelajaran dan berfungsi untuk memperjelas makna informasi yang disampaikan sehingga dapat mencapai tujuan pembelajaran dengan hasil yang baik dan sempurna. Menurut Kustandi, dkk (2013:30) media audio visual adalah cara untuk membantu menghasilkan atau menyampaikan materi dengan menggunakan mesin mekanis dan elektronik, untuk menyajikan pesan-pesan dan informasi melalui audio dan visual. menurut Sidi \& Mukminan (2016:54) penggunaan media audio visual dalam pembelajaran di kelas dapat bermanfaat untuk memotivasi siswa sehingga dapat meningkatkan hasil belajar yang dicapai baik berupa pengetahuan (kognitif), sikap (afektif), dan keterampilan (psikomotorik).

Tujuan dari penelitian ini adalah meningkatkan kemampuan berpikir kritis siswa dengan penerapan model pembelajaran Problem Based Learning (PBL) Berbantu Media Audio Visual pada siswa kelas 4 SD N Ledok 07 Salatiga semester II tahun ajaran 2017/2018.

\section{METODE PENELITIAN}

Jenis penelitian ini adalah Penelitian Kualitatif yaitu berupa Penelitian Tindakan Kelas (PTK). Menurut Arikunto (2013:16) pada pelaksanaan tindakan kelas setiap siklus terdiri atas 4 tahap yang lazim dilalui, yaitu perencanaan tindakan, pelaksanaan tindakan, observasi, dan refleksi. Prosedur tersebut dilakukan secara berulang sampai perbaikan atau peningkatan yang diharapkan tercapai. Penelitian ini dilakukan pada pembelajaran Tema 7 Indahnya Keragaman di Negeriku Subtema 2 Indahnya Keragaman Budaya Negeriku dengan menggunakan model pembelajaran problem based learning berbantuan media audio visual. Penelitian ini dilaksanakan di SD Negeri Ledok 07 Salatiga. Subjek penelitian ini yaitu siswa kelas 4 SD Negeri Ledok 07 Salatiga semester II tahun ajaran 2017/2018. dengan jumlah siswa kelas 4 adalah sebanyak 29 orang yang terdiri dari 16 siswa putra dan 13 siswa putri. Data berasal dari siswa kelas 4, guru kelas 4, teman sejawat atau observer, dan dokumentasi. Teknik pengumpulan data menggunakan tes uraian, dan lembar observasi. Analisis data yang digunakan adalah analisis data kuantitatif dan kualitatif. Penelitian tindakan kelas ini dilaksanakan selama dua siklus masing-masing siklus dua pertemuan. Setiap pertemuan terdiri dari perencanaan, pelaksanaan, observasi, dan refleksi.

Tempat penelitian berada di SD $\mathrm{N}$ Ledok 07 Salatiga, yang beralamat $\mathrm{Jl}$. Veteran 43 A RT/RW 05/01 Dusun Ringinawe Kelurahan Ledok Kecamatan Argomulyo Kota Salatiga. Penelitian dilaksanakan pada akhir tahun pelajaran 2017/2018 semester II. Waktu pelaksanaan diawali dengan pembuatan proposal pada bulan November minggu ke- 2 dan penyusunan instrument pada JanuariFebruari minggu ke- 1, selanjutnya dilaksanakan pengumpulan data yang dilakukan pada bulan Maret minggu ke- 3 dan minggu ke- 4. Pelaksanaan penelitian tindakan kelas ini meliputi 2 siklus dimana setiap siklus dilakukan dua kali pertemuan. Siklus pertama dilaksanakan pada bulan Maret minggu ke- 3 hari selasa-rabu, sedangkan siklus kedua dilaksanakan pada 
bulan Maret minggu ke- 4 hari selasa-rabu. Selanjutnya dilakukan analisis dan diskusi pada bulan Maret minggu ke- 4. Pengolahan data, penyusunan laporan, dan konsultasi laporan dilakukan pada bulan April minggu ke- 1, 2 dan minggu ke- 3. Dalam penelitian variabel bebasnya adalah model Problem Based Learning berbantu media audio visual, sedangkan variabel terikatnya adalah peningkatan kemampuan berpikir kritis Tema 7 Indahnya Keragaman di Negeriku Subtema 2 Indahnya Keragaman Budaya Negeriku siswa kelas 4 SD N Ledok 07 Salatiga.

Dalam penelitian ini akan diperoleh data hasil observasi dan data hasil tes evaluasi kemampuan berpikir kritis. Data yang diperlukan dalam penelitian ini ialah: (1) data hasil observasi kegiatan guru dalam penerapan model pembelajaran problem based learning berbantu media audio visual, (2) data hasil observasi aktivitas siswa dalam penerapan model pembelajaran problem based learning berbantu media audio visual, (3) data hasil observasi kemampuan berpikir kritis siswa, (4) data hasil tes evaluasi kemampuan berpikir kritis siswa. Indikator keberhasilan dalam penelitian ini adalah kemampuan berpikir kritis siswa secara klasikal meningkat hingga $70 \%$ dari jumlah keseluruhan siswa.

\section{HASIL DAN PEMBAHASAN Hasil}

Perencanaan dalam penelitian ini diawali dengan penyusunan perangkat pembelajaran, Rencana Pelaksanaan Pembelajaran (RPP), bahan ajar, media, Lembar Kerja Siswa (LKS), kriteria penilaian, lembar observasi kemampuan berpikir kritis dan soal evaluasi kemampuan berpikir krtis. Selanjutnya, pelaksanaan tindakan Penelitian pada siklus I terdiri dari 2 pertemuan 3 pembelajaran dan 1 kali evaluasi. Pada kegiatan awal memeriksa kesiapan ruang, alat pembelajaran, media pembelajaran dan mengecek kesiapan siswa, berdo'a, mengucapkan salam, melakukan presensi, apersepsi, menyampaikan tujuan pembelajaran, memberikan motivasi kepada siswa. Pada kegiatan inti dilakukan penerapan pembelajran dengan model problem based learning berbantu media audio visual dengan menampilkan video pembelajaran melalui LCD, untuk memunculkan permasalahan, guru dan siswa bertanya jawab seputar video yang di tampilkan, memberikan penjelasan materi melalui video, siswa dibagi kedalam 6 kelompok, siswa melakukan diskusi dan membuat hasil laporan, kemudian setiap perwakilan kelompok maju mempersentasikan hasil diskusinya, setelah semua kelompok selesai mempersentasikan guru memberikan umpan balik, guru bersama siswa. Pada kegiatan akhir Peneliti menanyakan perasaan siswa setelah mengikuti pembelajaran apakah pembelajarannya mudah dipahami atau sulit dipahami. Hal ini dilakukan untuk memperbaiki pembelajaran untuk pertemuan selanjutnya. Memberikan reward kepada siswa yang aktif dalam pembelajaran. Merefleksi pembelajaran yang sudah dipelajari dengan menyimpulkan pembelajaran hari ini. Guru memberikan PR.

Observasi yang dilakukan digunakan untuk memperoleh data hasil kegiatan guru dan aktivitas siswa dengan penerapan model problem based learning berbantu media audio visual, dan data kemampuan berpikir kritis siswa. Refleksi dilakukan untuk mengetahui keberhasilan dari proses pembelajaran serta kelemahan dan kelebihan.

Setiap pertemuan untuk lembar observasi kegiatan guru dalam menerapkan model pembelajaran problem based learning berbantu media audio visual terdapat 28 pernyataan. Hasil observasi kegiatan guru pada siklus I dan II dapat dilihat pada Table 2. 
Tabel 2. Data Hasil Observasi Tindakan Guru Dalam Menerapkan Model Pbl Berbantu Media Audio Visual

\begin{tabular}{ccccc}
\hline \multirow{2}{*}{ Pertemuan } & \multicolumn{2}{c}{ Siklus I } & \multicolumn{2}{c}{ Siklus II } \\
\cline { 2 - 5 } & $\begin{array}{c}\text { Sintak yang } \\
\text { terlaksana }\end{array}$ & $\%$ & $\begin{array}{c}\text { Sintak yang } \\
\text { terlaksana }\end{array}$ & $\%$ \\
\hline 1 & 24 & 86 & 27 & 96 \\
2 & 27 & 96 & 28 & 100 \\
\hline
\end{tabular}

Berdasarkan Tabel 2 data hasil observasi kegiatan guru dalam menerapkan model problem based learning berbantu media audio visual dari 28 pernyataan, guru pada siklus I pertemuan pertama guru tidak melakukan 4 langkah yang telah dibuat. Pada siklus I pertemuan kedua guru tidak melakukan 1 langkah yang telah dibuat, sedangkan pada siklus II pertemuan pertama guru tidak melakukan 1 langkah yaitu pemberian soal evaluasi dikarenakan soal

Tabel 3. Data Hasil Observasi Aktivitas Siswa Dalam Menerapkan Model Pbl Berbantu Media Audio Visual evaluasi akan diberikan pada pertemuan kedua. Pada siklus II pertemuan kedua guru telah melakukan semua langkah.

Kemudian peneliti melakukan observasi aktivitas siswa selam pembelajran dengan menerapkan model problem based learning berbantu media audio visual. Terdapat 30 pernyataan. Hasil observasi aktivitas siswa pada siklus I dan II dapat dilihat pada Tabel 3 .

\begin{tabular}{ccccc}
\hline \multirow{2}{*}{ Pertemuan } & \multicolumn{2}{c}{ Siklus I } & \multicolumn{2}{c}{ Siklus II } \\
\cline { 2 - 5 } & $\begin{array}{c}\text { Sintak yang } \\
\text { terlaksana }\end{array}$ & $\%$ & $\begin{array}{c}\text { Sintak yang } \\
\text { terlaksana }\end{array}$ & $\%$ \\
\hline 1 & 21 & 70 & 29 & 98 \\
2 & 28 & 93 & 30 & 100 \\
\hline
\end{tabular}

Berdasarkan Tabel 3 data hasil observasi aktivitas siswa dalam menerapkan model problem based learning berbantu media audio visual dari 30 pernyataan, guru pada siklus I pertemuan pertama siswa tidak melakukan 9 langkah yang telah dibuat. Pada siklus I pertemuan kedua siswa tidak melakukan 2 langkah yang telah dibuat, sedangkan pada siklus II pertemuan pertama siswa tidak melakukan 1 langkah yaitu pemberian soal evaluasi dikarenakan soal evaluasi akan diberikan pada pertemuan kedua. Pada siklus II pertemuan kedua siswa telah melakukan semua langkah. 
Tabel 4. Data Hasil Observasi Kemampuan Berpikir Kritis Siswa Pada Prasiklus, Siklus I Dan Siklus II

\begin{tabular}{|c|c|c|c|c|}
\hline \multirow[b]{2}{*}{ No } & \multirow[b]{2}{*}{ Indikator } & \multirow{2}{*}{$\begin{array}{c}\text { Pra Siklus } \\
\begin{array}{c}\text { Skor Rata-rata } \\
\text { (Kriteria) }\end{array} \\
\end{array}$} & \multirow{2}{*}{$\begin{array}{c}\text { Siklus I } \\
\begin{array}{c}\text { Skor Rata-rata } \\
\text { (Kriteria) }\end{array} \\
\end{array}$} & \multirow{2}{*}{$\begin{array}{c}\text { Siklus II } \\
\begin{array}{c}\text { Skor Rata-rata } \\
\text { (Kriteria) }\end{array} \\
\end{array}$} \\
\hline & & & & \\
\hline 1 & Menganalisi argumen & $\begin{array}{c}48 \text { (Sangat Tidak } \\
\text { Kritis) }\end{array}$ & 62 (Cukup Kritis) & $\begin{array}{l}\text { 69,5 (Cukup } \\
\text { Kritis) }\end{array}$ \\
\hline 2 & Mampu bertanya & 52 (Tidak Kritis) & 65 (Cukup Kritis) & 72,5 (Kritis) \\
\hline 3 & $\begin{array}{l}\text { Mampu menjawab } \\
\text { pertanyaan }\end{array}$ & 53 (Tidak Kritis) & 62 (Cukup Kritis) & 74,5 (Kritis) \\
\hline 4 & Memecahkan masalah & $\begin{array}{c}44 \text { (Sangat Tidak } \\
\text { Kritis) }\end{array}$ & $\begin{array}{c}\text { 56,5 (Cukup } \\
\text { Kritis) }\end{array}$ & 73 (Kritis) \\
\hline 5 & Membuat kesimpulan & 50 (Tidak Kritis) & 53 (Tidak Kritis) & $\begin{array}{l}67 \text { (Cukup } \\
\text { Kritis) }\end{array}$ \\
\hline 6 & $\begin{array}{l}\text { Mengevaluasi dan } \\
\text { menilai hasil } \\
\text { pengamatan }\end{array}$ & 51 (Tidak Kritis) & 54 (Tidak Kritis) & $\begin{array}{l}68 \text { (Cukup } \\
\text { Kritis) }\end{array}$ \\
\hline 7 & Keseluruhan & $\begin{array}{l}49,7 \text { (Sangat tidak } \\
\text { kritis) }\end{array}$ & $\begin{array}{l}\text { 59,8 (Cukup } \\
\text { Kritis) }\end{array}$ & 70 (Kritis) \\
\hline & Nilai rata-rata & $\begin{array}{c}57 \text { (Sangat tidak } \\
\text { kritis) }\end{array}$ & $\begin{array}{c}\text { 67,5 (Cukup } \\
\text { Kritis) }\end{array}$ & 81,3(Kritis) \\
\hline & $\begin{array}{l}\text { rsentase siswa minimal } \\
\text { cukup kritis }\end{array}$ & $13,8 \%$ & $69 \%$ & $96,5 \%$ \\
\hline
\end{tabular}

Pada pra siklus hasil kemampuan berpikir kritis skor rata-rata kelas setiap 6 indikator berpikir kritis masih tergolong pada kriteria tidak kritis dan sangat tidak kritis. Hal-hal tersebut menunjukkan bahwa siswa tidak secara aktif memahami, menganalisis dan mengevaluasi apa yang disampaikan oleh guru baik dalam penyampaian materi maupun pemecahan masalah atau dengan kata lain kemampuan berpikir kritis siswa masih rendah. Pada siklus I skor rata-rata kelas menunjukkan bahwa dari 6 indikator berpikir kritis terdapat 4 indikator berpikir kritis yang tergolong kriteria cukup krirtis. Sedangkan 2 indikator tergolong kriteria tidak kritis. Pada saat mengerjakan LKS siswa sudah mampu menganalisi argumen berdasarkan alasan yang kuat, saat guru mengajukan pertanyaan terdapat 8 siswa yang merespon dan menjawab pertanyaan dari guru, ada 3 siswa yang ditunjuk guru tidak bisa menjawab pertanyaan dari peneliti, siswa sudah berani mengajukan pertanyaan kritis berdasarkan video atau materi yang telah disampaikan, dalam kelompok siswa sudah bisa memecahkan masalah dengan sistematis tanpa bantuan peneliti. Tetapi dalam membuat kesimpulan siswa masih kesulitan karena dalam pembelajaran siswa tidak terbiasa dalam membuat kesimpulan sehingga kesimpulan yang dibuat tidak sesuai dengan materi, dalam mengevaluasi dan menilai hasil pengamatan siswa masih tidak fokus pada yang diamati.

Pada siklus II skor rata-rata kelas menunjukkan bahwa dari 6 indikator kemampuan berpikir kritis 3 indikator berpikir kritis tergolong kriteria cukup kritis dan 3 indikator berpikir krtis tergolong kriteria kritis. Hal ini menunjukkan bahwa siswa sudah bisa menganalisis argumen dengan alasan yang kuat, siswa sudah berani mengajukan pertanyaan dan bertanya kembali ketika ada yang belum jelas, siswa mampu menjawab pertanyaan dari guru berdasarkan pengetahuan dan pengalamannya, siswa mampu memecahkan masalah dengan sistematis tanpa bantuan dari guru, siswa sudah mampu membuat kesimpulan sesuai dengan materi dengan bahasa yang baik dan benar, siswa mampu mengevaluasi dan menilai hasil pengamatan dengan tepat. 
Berdasarkan hasil analisis, dapat dilihat bahwa kemampuan berpikir kritis siswa kelas 4 SD Negeri Ledok 07 Salatiga mengalami peningkatan setelah menerapkan model problem based learning berbantu media audio visual. Pada hasil observasi kemampuan berpikir kritis siswa yang terdiri dari 6 indikator berpikir kritis yang di adopsi dari beberapa ahli yaitu: (1) mengananlisis argument (2) mampu bertanya (3) mampu menjawab pertanyaan (4) memecahkan masalah (5) membuat kesimpulan (6) ketrampilan mengevaluasi dan menilai hasil pengamatan. Dari prasiklus sampai dengan siklus I dan siklus II dalam penerapan model problem based learning berbantu media audio visual mengalami peningkatan yakni terlihat dari skor rata-rata kelas pada setiap siklus mengalami peningkatan.
Kemampuan berpikir kritis siswa diperoleh melalui tes evaluasi kemampuan berpikir kritis berupa soal uraian, soal yang dibuat berdasarkan indikator berpikir kritis yang terdiri dari: (1) mengananlisis argument (2) mampu bertanya (3) mampu menjawab pertanyaan (4) memecahkan masalah (5) membuat kesimpulan (6) ketrampilan mengevaluasi dan menilai hasil pengamatan, dan berpedoman pada ranah $\mathrm{C} 4$ sampai dengan C6 dari Taksonomi Bloom, dimana setiap soal mewakili indikator berpikir kritis tersebut. Tes evaluasi diberikan disetiap akhir siklus I dan siklus II. Hasil tes evaluasi kemampuan berpikir kritis siswa kelas 4 pada siklus I dan II dapat dilihat pada Tabel 5.

Tabel 5. Data Hasil Evaluasi Kamampuan Berpikir Kritis Siswa Pada Siklus I Dan Siklus II

\begin{tabular}{|c|c|c|c|c|c|c|c|}
\hline \multirow[b]{2}{*}{ No } & \multirow[b]{2}{*}{ Indikator } & \multicolumn{3}{|c|}{ Siklus I } & \multicolumn{3}{|c|}{ Siklus II } \\
\hline & & $\begin{array}{l}\text { Nilai } \\
\text { Rata- } \\
\text { rata }\end{array}$ & $\begin{array}{c}\% \\
\text { Jumlas } \\
\text { Siswa } \\
\text { Minimal } \\
\text { Cukup } \\
\text { Kritis } \\
\end{array}$ & Kriteria & $\begin{array}{c}\text { Nilai } \\
\text { Rata- } \\
\text { rata }\end{array}$ & $\begin{array}{c}\% \\
\text { Jumlas } \\
\text { Siswa } \\
\text { Minimal } \\
\text { Cukup } \\
\text { Kritis } \\
\end{array}$ & Kriteria \\
\hline 1 & $\begin{array}{l}\text { Menganalisis } \\
\text { Argumen }\end{array}$ & 54,8 & $31,03 \%$ & $\begin{array}{l}\text { Sangat } \\
\text { tidak } \\
\text { kritis }\end{array}$ & 93,1 & $93,1 \%$ & $\begin{array}{l}\text { Sangat } \\
\text { kritis }\end{array}$ \\
\hline 2 & Mampu bertanya & 62,1 & $38 \%$ & $\begin{array}{l}\text { Tidak } \\
\text { kritis }\end{array}$ & 82,1 & $89,7 \%$ & Kritis \\
\hline 3 & $\begin{array}{l}\text { Mampu } \\
\text { menjawab } \\
\text { pertanyaan }\end{array}$ & 63,4 & $48,3 \%$ & $\begin{array}{l}\text { Tidak } \\
\text { kritis }\end{array}$ & 84,1 & $100 \%$ & Kritis \\
\hline 4 & $\begin{array}{l}\text { Memecahkan } \\
\text { masalah }\end{array}$ & 76 & $65,5 \%$ & $\begin{array}{l}\text { Cukup } \\
\text { kritis }\end{array}$ & 87,2 & $93,1 \%$ & Kritis \\
\hline 5 & $\begin{array}{l}\text { Membuat } \\
\text { Kesimpulan }\end{array}$ & 60 & $14,8 \%$ & $\begin{array}{l}\text { Tidak } \\
\text { kritis }\end{array}$ & 92,4 & $89,6 \%$ & $\begin{array}{c}\text { Sangat } \\
\text { kritis }\end{array}$ \\
\hline 6 & $\begin{array}{l}\text { Ketrampilan } \\
\text { mengevaluasi } \\
\text { dan menilai hasil } \\
\text { pengamatan }\end{array}$ & 70 & $69 \%$ & $\begin{array}{l}\text { Cukup } \\
\text { kritis }\end{array}$ & 89,1 & $93,1 \%$ & $\begin{array}{l}\text { Sangat } \\
\text { kritis }\end{array}$ \\
\hline 7 & Keseluruhan & 64,2 & $44,8 \%$ & $\begin{array}{l}\text { Tidak } \\
\text { kritis }\end{array}$ & 87,2 & $96,6 \%$ & Kritis \\
\hline
\end{tabular}

Berdasarkan Tabel 5 data hasil evaluasi kemampuan berpikir kritis siswa dapat diketahui data hasil tes uraian kemampuan berpikir kritis siswa dari siklus I dan siklus II. Pada data siklus I indikator 1 menganalisis argument diperoleh nilai kemampuan berpikir kritis 54,8 yang tergolong kriteria "sangat tidak kritis" 
kemudian data siklus II indikator 1 menganalisis argument.meningkat dengan nilai kemampuan berpikir kritis 93,1 yang tergolong kritieria "sangat kritis". Pada data siklus I indikator 2 mampu bertanya diperoleh nilai kemampuan berpikir kritis 62,1 yang tergolong pada kriteria "tidak kritis" kemudian data siklus II indikator 2 mampu bertanya meningkat dengan nilai kemampuan berpikir kritis 82,1 yang tergolong kriteria "kritis". Pada data siklus I indikator 3 mampu menjawab pertanyaan diperoleh nilai kemampuan berpikir kritis 63,4 yang tergolong "tidak kritis" kemudian data siklus II indikator 3 mampu menjawab pertanyaan meningkat dengan nilai kemampuan berpikir kritis 84,1 yang tergolong kriteria "kritis". Pada data siklus I indikator 4 memecahkan masalah diperoleh nilai kemampuan berpikir kritis dengan nilai 76 yang tergolong "cukup kritis" kemudian data siklus II indikator 4 memecahkan masalah diperoleh nilai kemampuan berpikir kritis 87,2 yang tergolong kriteria "kritis". Pada data siklus I indikator 5 membuat kesimpulan diperoleh nilai kemampuan berpikir kritis 60 yang tergolong kritieria "tidak kritis" kemudian data siklus II indikator 5 membuat kesimpulan diperoleh nilai kemampuan berpikir kritis 92,4 yang tergolong kritieria "sangat kritis". Pada data siklus I indikator 6 ketrampilan mengevaluasi dan menilai hasil pengamatan diperoleh nilai kemampuan berpikir kritis 70 yang tergolong cukup kritis" kemudian data siklus II indikator 6 ketrampilan mengevaluasi dan menilai hasil pengamatan diperoleh nilai kemampuan berpikir kritis 89,1 yang tergolong kriteria "sangat kritis. Selanjutnya nilai keseluruhan indikator siklus I diperoleh nilai 64,2 yang tergolong kriteria "tidak kritis" kemudian pada siklus II mengalami peningkatan dengan nilai keseluruhan indikator diperoleh nilai 87,2 yang tergolong kriteria "kritis".

Selanjutnya peneliti merangkum perbandingan persentase jumlah siswa yang minimal cukup kritis pada siklus I dan siklus II. Yang dijabarkan dalam bentuk gambar 1 .

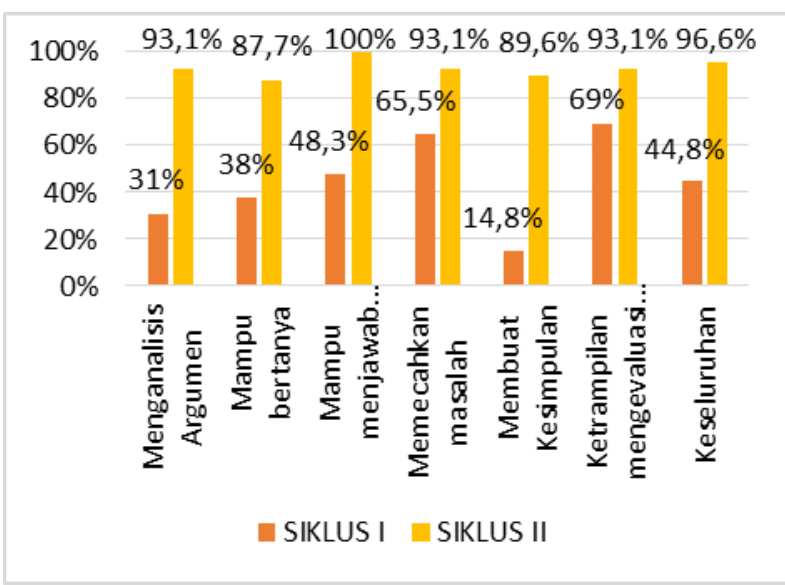

Gambar 1. Perbandingan persentase jumlah siswa yang minimal cukup kritis

Berdasarkan Gambar 1 dapat dilihat bahwa jumlah siswa yang minimal cukup kritis mengalami peningkatan. Pada data siklus I indikator 1 menganalisis argument persentase jumlah siswa minimal cukup kritis $31 \%$ kemudian meningkat pada siklus II menjadi 93,1. Pada data siklus I indikator 2 mampu bertanya persentase jumlah siswa minimal cukup kritis $38 \%$ kemudian meningkat pada siklus II menjadi $87,7 \%$. Pada data siklus I indikator 3 mampu menjawab pertanyaan persentase jumlah siswa minimal cukup kritis $48,3 \%$ kemudian meningkat pada siklus II menjadi $100 \%$. Pada data siklus I indikator 4 memecahkan masalah persentase jumlah siswa minimal cukup kritis $65,5 \%$ kemudian meningkat pada siklus II menjadi 93,1\%. Pada data siklus I indikator 5 membuat kesimpulan persentase jumlah siswa minimal cukup kritis $14,8 \%$ kemudian meningkat pada siklus II menjadi $89,6 \%$. Pada data siklus I indikator 6 ketrampilan mengevaluasi dan menilai hasil pengamatan persentase jumlah siswa minimal cukup kritis $69 \%$ kemudian meningkat pada siklus II menjadi $93,1 \%$. Selanjutnya kesuluruhan indikator pada data siklus I persentase jumlah siswa yang minimal cukup kritis $44,8 \%$ meningkat pada siklus II menjadi 96,5\%.

\section{Pembahasan}

Dengan menerapkan model problem based learning berbantu media audio visual dalam pembelajaran, dari hasil observasi kemampuan berpikir kritis mengalami 
peningkatan jika dibandingkan dengan hasil prasiklus yang belum menggunakan model problem based learning berbantu media audi visual, pada model pembelajaran ini siswa dihadapkan pada masalah yang terdapat dalam video yang ditampilkan di LCD siswa diminta untuk dapat memecahkan permasalahan secara individu dan kelompok sehingga siswa dapat saling bertukar pikiran bersama teman-teman kelompoknya. Guru juga meminta siswa untuk mengerjakan lembar kerja siswa (LKS) sebagai alat bantu agar siswa lebih paham dengan materi yang disampaikan dan siswa mampu memecahkan masalah yang diberikan dengan berdiskusi bersama anggota kelompoknnya. Dengan menggunakan LKS diharapkan siswa mampu bertanggung jawab dan bekerja sama dengan anggota kelompoknya, guru membimbing siswa dengan cara menanyakan kesulitan apa yang siswa alami dan guru memberi alternative berupa pertanyaan untuk memancing jawaban siswa. Dengan meningkatkan aktivitas guru dalam pelaksanaan pembelajaran, aktivitas siswa dalam pembelajaran juga meningkat pada setiap siklus. Pembelajaran tematik menggunakan model problem based learning berbantu media audio visual tidak terfokus pada guru. Guru membimbing dan memberikan pengarahan kepada kelompok yang mengalami kesulitan, sedangkan siswa bersama anggota kelompoknya melakukan diskusi untuk memecahkan masalah yang diberikan oleh peneliti. Pada pembelajaran siklus I dalam melakasanakan diskusi kelompok siswa sudah mau bertanya dan menjawab pertanyaan, dapat mengevaluasi dan menilai hasil pengamatan, siswa masih kesulitan menganalisis dan membuat kesimpulan, meskipun terjadi peningkatan pada siklus I akan tetapi pelaksanaan siklus I masih memiliki kekurangan. Kekurangannya ialah siswa tidak terbiasa bekerja dalam kelompok sehingga siswa cenderung bermain dan bermain dengan temannya sehingga laporan kelompok hanya dikerjakan beberapa anggotanya. Alokasi waktu kurang karena masalah yang disajikan terlalu banyak. Pada akhir siklus I peneliti memberikan soal tes evaluasi untuk mengukur kemampuan berpikir kritis siswa.
Berdasarkan skor tes evaluasi kemampuan berpikir kritis siklus I, jumlah siswa yang minimal cukup kritis sebanyak 13 siswa dengan $44,8 \%$ dari 29 siswa. pada siklus I

Kemudian, peneliti menyusun rencana untuk melakukan perbaikan pada pelaksanaan siklus II. Pada siklus II, hasil lembar observasi rata-rata skor kelas sudah menunjukkan kriteria keberhasilan yang ditentukan yaitu "kritis". Dengan pemberian motivasi yang lebih baik, aktivitas siswa menjadi meningkat dibandingkan dengan siklus I. siswa sudah mulai terbiasa dengan bekerja bersama kelompok dan sudah bisa berdiskusi dengan anggota kelompoknya. Suasana kelas lebih terkoordinasi karena siswa antusias dalam mengikuti pembelajaran. Siswa sudah berani mengajukan pertanyaan ketika peneliti memberikan jawaban siswa masih merasa kurang puas dan mengajukan pertanyaan kembali, menjawab pertanyaan yang diberikan oleh guru, dalam bekerja kelompok siswa mampu menganalisi argument dengan baik dan benar, siswa dan kelompok mampu memecahkan masalah dengan benar dan baik, siswa mampu membuat kesimpulan berdasarkan fakta, dan siswa mampu menilai dan mengevaluasi hasil pengamatan dengan baik dan benar sesuai fakta. Pada saat persentasi, siswa sudah berani mengemukakan pendapatnya kepada kelompok yang sedang persentasi. Pada akhir siklus II, peneliti memberikan tes evaluasi kemampuan berpikir kritis siswa. berdasarkan pada hasil tes evaluasi kemampuan berpikir kritis siklus II, jumlah siswa yang minimal cukup kritis meningkat menjadi 28 siswa jika dipresentasikan menjadi $96,55 \%$. Peningkatan pada siklus I sampai dengan siklus II yaitu sebesar 51,9\% sehingga pelaksanaan siklus II sudah memenuhi kriteria yang diinginkan yaitu sebanyak $70 \%$ siswa mampu menyelesaikan tes evaluasi tindakan siklus II yang bertujuan untuk mengukur kemampuan berpikir kritis pada pelaksanaan pembelajaran tema 7 Indahnya Keragaman di Negeriku subtema 2 Indahnya Keragaman Budaya dengan menggunakan model pembelajaran problem based learning berbantu media audio visual. 
Berdasarkan observasi dan refleksi yang dilakukan guru, pada pelaksanaan pembelajaran pembelajaran tema 7 Indahnya Keragaman di Negeriku subtema 2 Indahnya Keragaman Budaya dengan menggunakan model pembelajaran problem based learning berbantu media audio visual. Telah sesuai dengan yang diharapkan. Sebagian besar siswa sudah menunjukkan kemampuan berpikir kritisnya dalam pembelajaran. Hasil penelitian ini juga menunjukkan bahwa siswa dapat mengikuti pembelajaran dengan model pembelajaran problem based learning berbantu media audio visual sehingga kemampuan berpikir kritis siswa berangsurangsur mengalami peningkatan. berdasarkan penelitian yang relevan yang dilakukan oleh Syaribuddin, Ibnu Khaldun, Musri. Hasil penelitian dan pembahasan membuktikan model problem based learning berbantu media audio visual mampu meningkatkan kemampuan berpikir kritis siswa.

Penelitian relevan yang dilakukan oleh Arief Trihandoko Saputra (2015) hasil penelitian menunjukkan pelaksanaan pembelajaran kemampuan berpikir kritis dengan menggunakan model Problem Based Learning dalam pembelajaran tematik mengalami peningkatan ditinjau dari aspek guru dan aspek siswa.

Penelitian yang dilakukan oleh Nopia, Julia, \& Sujana (2016)dalam Jurnal Pena Ilmiah, tahun 2016 yang berjudul "Pengaruh Model Problem Based Learning Terhadap Keterampilan Berpikir Kritis Siswa Sekolah Dasar Pada Materi Daur Air" meskipun diterapkan pada mata pelajaran yang berbeda terbukti model problem based learning yang dilandasi dengan pemberian masalah kepada siswa untuk dipecahkan dapat meningkatkan keterampilan berpikir kirtis siswa.

\section{SIMPULAN DAN SARAN}

Berdasarkan hasil penelitian
tindakan kelas (PTK) yang telah dilaksanakan di SD Negeri Ledok 07 Salatiga tentang Penerapan Model Problem Based Learning (PBL) berbantu media audio visual dapat disimpulkan bahwa penerapan model problem based learning berbantu media audio visual dapat meningkatkan kemampuan berpikir kritis pada siswa kelas
4 SD Negeri Ledok 07 Salatiga. Peningkatan ini dapat dilihat dari perolehan skor rata-rata adalah 48,1 dengan nilai kemampuan berpikir 64,2 tergolong pada keriteria "Tidak kritis" dengan persentase jumlah siswa minimal cukup kritis $44,8 \%$. Pada data siklus II nilai kemampuan berpikir kritis meningkat skor rata-rata menjadi 61,03 dengan nilai kemampuan berpikir kritis 87,2 Yang tergolong pada kritieria "kritis" dengan persentase jumlah siswa yang minimal cukup kritis mencapai $96,5 \%$. Hal ini di perkuat juga dengan hasil observasi kemampuan berpikir kritis siswa pada prasiklus diperoleh nilai rata-rata kemampuan berpikir kritis 57 yang tergolong pada kriteria "sangat tidak kritis" dengan persentase siswa minimal cukup kritis sebesar 13,8\%, pada siklus I mengalami peningkatan dengan perolehan nilai rata-rata 67,5 yang tergolong pada kriteria "cukup kritis" dengan persentase siswa minimal cukup kritis sebesar 69\%, pada siklus II mengalami peningkatan dengan perolehan nilai rata-rata 81,3 yang tergolong pada kriteria "kritis" dengan persentase siswa minimal cukup kritis sebesar 96,5\%. Berdasarkan observasi dan refleksi yang dilakukan peneliti, pada pelaksanaan pembelajaran dengan menggunakan model pembelajaran problem based learning berbantu media audio visual. Telah sesuai dengan yang diharapkan, sebagian besar siswa sudah menunjukkan kemampuan berpikir kritisnya dalam pembelajaran. Hasil penelitian ini juga menunjukkan bahwa siswa dapat mengikuti pembelajaran dengan model pembelajaran problem based learning berbantu media audio visual sehingga kemampuan berpikir kritis siswa berangsur-angsur mengalami peningkatan

Adapun saran berdasarkan hasil penelitian yang telah dilakukan, dan keterbatasan penelitian adalah Model Problem Based Learning berbantu media Audio Visual dapat digunakan sebagai salah satu alternatif model yang terbukti dapat meningkatkan kualitas pembelajaran. Bagi guru, dalam pembelajaran guru diharapkan dapat memanfaatkan media dan modelmodel pembelajaran degan lebih maksimal. Bagi siswa, dalam berdiskusi kelompok 
hendaknya siswa aktif dan harus berani mengemukakan pendapat, pertanyaan, argumen maupun memberikan jawaban. Bagi peneliti lain, penelitian ini dapat digunakan sebagai acuan kepada peneliti selanjutnya pada bidang yang sama.

\section{DAFTAR RUJUKAN}

Arikunto , S. (2013). Prosedur Penelitian Suatu Pendekatan Praktik. Jakarta: PT Rineka Cipta.

Christina, L. V., \& Kristini, F. (2016). Efektifitas Model Pembelajaran Tipe Group Investigation (GI) dan Cooperatif Integrated Reading And Composition (CIRC) dalam Meningkatkan Kreativitas Berpikir Kritis dan Hasil Belajar IPS Siswa Kelas 4. Sholaria: Jurnal pendidikan dan kebudayaan, 6(2), 217-230.

Faiz, F. (2012). Thingking Skill, pengantar menuju berpikir kritis. Yogyakarta: SUKA-Press.

Fakhriyah, F. (2014). Penerapan Model Problem Based Learning dalam Upaya Mengembangkan Kemampuan Berpikir Kritis Mahasiswa. Jurnal Pendidikan IPA Indonesia, 3(1), 95-101.

Kustandi, Cecep, \& Sutjipto, B. (2013). Media Pembelajaran Manual dan Digital. Jakarta: Ghalia Indonesia.

Nopia, R., Julia, \& Sujana, A. (2016). Pengaruh Model Problem Based Learning Terhadap Ketrampilan Berpikir Kritis Siswa Sekolah Dasar Pada Materi Daur Air. Jurnal Pena Ilmiah, 1, No.1, 641-650.

Puspita, V., \& Yuhelman, N. (2017, April). Peningkatan Proses Pembelajaran Tematik dengan Menggunakan Pendekatan Problem Based Learning di Kelas III SD. Pendidikan dan Keguruan, VIII No.1.

Rahmadani, N., \& Anugraheni, I. (2017). Peningkatan Aktivitas Belajar Matematika melalui Problem Based Learning Bagi Siswa Kelas 4 SD.
Sholaria: Jurnal Pendidikan dan Kebudayaan, 7(3), 241-250.

Rahmawati , A., \& Hizqiyah , I. N. (2017, Juni). Implementasi Model Pembelajaran Problem Based Learning untuk Meningkatkan Penguasaan Defisiensi Nutrisi Tumbuhan pada Mahasiswa Pendidikan Biologi Universitas Pasundan. J. Bio \& Pend.Bio, 2, No.1, 21-25.

Redhana, I. W. (2012, November). Model Pembelajaran Berbasis Masalah dan Pertanyaan Sockratik untuk Meningkatkan Ketrampilan Berpikir Kritis Siswa. Cakrawala pendidikan, XXXI, No.3.

Rusyna, A. (2014). Ketrampilan berpikir. Yogyakarta: Ombak.

Saputra, A. T. (2015). Peningkatan Kemampuan Berpikir Kritis Menggunakan Model Problem Based Learning (PBL) pada Pembelajaran Tematik Terpadu di Sekolah Dasar. e-Jurnal Inovasi Pembelajaran SD, 1, 1-16.

Sidi, J., \& Mukminan. (2016, Juni). Penggunaan Media Audiovisual untuk Meningkatkan Hasil belajar IPS di SMP. Socia, 15. No.1, 52-72.

Suparno, \& Iranto, D. (2014, Oktober). The Effect of PBL Method Using The Hypermedia to The Student' Critical Thinking Skill on The Social Studies Subject. Jurnal Pendidikan Ekonomi dan Bisnis (JPEB), 2 No.2, 40-52.

Syaribuddin, Ibnu Khaldun, \& Musri . (n.d.). Penerapan Model Pembelajaran Problem Based Learning (PBL) dengan Media Audio Visual pada Materi Ikatan Kimia Terhadap Penguasaan Konsep dan Berpikir Kritis Peserta Didik Sma Negeri 1 Panga. Jurnal Pendidikan Sains Indonesia, Vol. 04, No.02, hlm 96105, 2016 .

Virgiana, A., \& Wasitohadi, W. (2016). Efektifitas Model Problem Based Learning Berbantu Media Audio 
Visual Ditinjau dari Hasil Belajar IPA Siswa Kelas 5 SDN Gadu Ambong-Blora Semester 2 Tahun 2014/2015. Scholaria: Jurnal Pendidikan dan Kebudayaan, 6 (2), 100-118.

Zakiyah, S., Suryandari, K. C., \& Wahyudi. (2017). Peningkatan Ketrampilan Berpikir Kritis Melalui Model Pembelajaran Problem Based Learning (PBL) pada Pembelajaran IPA Tentang Gaya Siswa kelas V SD Negeri 1 Gebangsari Tahun ajaran 2016/2017. Kalam Cendekia, 5, No.3, 231-237. 